\title{
iCourts
}

iCourts Working Paper Series, no. 231, 2021

\section{The Ideological Shade of the Constitutional Order: Public Law and Political Economy in the Eurozone}

\author{
Hjalte Lokdam
}

IMAGINE Paper No. 14

Conference EU Constitutional Imagination: Between Ideology and Utopia

\author{
iCourts - The Danish National Research Foundation's \\ Centre of Excellence for International Courts
}




\begin{abstract}
:
This paper argues that the Economic and Monetary Union (EMU) created at Maastricht conformed to the neoliberal theory of interstate federalism in seeking to constitute structural conditions that circumscribed the effective exercise of activist public authority at both the Member State and European level. A response to a perceived 'crisis of governability,' it was designed to address the problem of excessive, and ineffective, governmental interventions in economic matters. By separating monetary and fiscal policy, the EMU ensured that no single public authority at the Member State or European level could control all the main levers of economic government. The Eurozone Crisis challenged this construct by emphasising the need for a coherent and effective exercise of public authority. The problem was thus no longer an excess of government but the absence of effective governmental authority for the EMU as a whole. Eurozone Crisis reforms introduced a greater scope for federal interventions in the domestic affairs of Member States and such reforms have elicited a new constitutional imaginary, expressed by European elites, that emphasises the need to generate 'European sovereignty.' This imaginary departs radically from the original EMU by foreseeing an omnicompetent European governmental apparatus that is able to intervene in, and control, economic developments across the Union in accordance with political objectives. The constitutional imaginary of the EMU can thus no longer meaningfully be called neoliberal. The early response to the COVID-19 Crisis, furthermore, highlights that the objectives pursued under the reformed EMU may depart from the set of policies traditionally associated with neoliberalism. What it should be called instead, however, remains unclear.
\end{abstract}

KEYWORDS: Economic and Monetary Union, Eurozone Crisis, neoliberalism, federalism, economic constitution, law and political economy

Hjalte Lokdam, ESRC Postdoctoral Fellow in the European Institute, LSE

E-mail: h.c.lokdam@,1se.ac.uk

IMAGINE has received funding from the European Research Council (ERC) under the European Union's Horizon 2020 research and innovation programme (grant agreement No 803163). 
This research is funded by the Danish National Research Foundation Grant no. DNRF105.

iCourts - Centre of Excellence for International Courts - focuses on the ever-growing role of international courts, their place in a globalizing legal order, and their impact on politics and society at large. To understand these crucial and contemporary interplays of law, politics, and society, iCourts hosts a set of deeply integrated interdisciplinary research projects on the causes and consequences of the proliferation of international courts.

iCourts opened in March 2012. The centre is funded by a large grant from the Danish National Research Foundation (for the period 2012-18). 
The Ideological Shade of the Constitutional Order: Public Law and Political Economy in the Eurozone

\section{Hjalte Lokdam, LSE}

\section{Introduction}

Does the constitutional imaginary embodied in the European Economic and Monetary Union's (EMU) public law structure express a particular ideology of economic government? If so, has this changed following the Eurozone Crisis? This chapter addresses these questions by analysing the vision of economic government embodied in the EMU's public law framework as constituted in Maastricht, how the crisis challenged this vision, and how the reformed EMU departs from the Maastricht vision of economic government.

The chapter answers both questions in the affirmative. The first section argues that the EMU constituted at Maastricht embodied a neoliberal theory of interstate federalism. Most eloquently elaborated by Hayek in 1939, ${ }^{1}$ this constitutional imaginary seeks to narrow the confines of governmental capacity with regard to economic affairs at all levels of government. This vision focusses on the structure and process of policymaking rather than the specific content of policies. That said, it presents a theory of what kind of outcomes to expect from the structural conditions of federalism. Such outcomes include traditional neoliberal policies such as deregulation, privatisation and fiscal consolidation. Importantly, however, it is not particular outcomes that it aims at but the general restriction of governmental activity. It seeks, in other words, to create a public law structure that makes it difficult (but not impossible) to exercise control over economic life politically, whether at the state or federal level.

From the perspective of analysing the public law framework established at Maastricht, it is irrelevant whether the framers of the Treaty had the neoliberal vision of federalism in mind

\footnotetext{
${ }^{1}$ Friedrich A Hayek, "The Economic Conditions of Interstate Federalism," in Individualism and Economic Order (Chicago, IL: The University of Chicago Press, 1948), 255-72; see also Wilhelm Röpke, International Order and Economic Integration (Dordrecht-Holland: D. Reidel Publishing Company, 1959); and Lionel Robbins, Economic Planning and International Order (London: Macmillan and Co., Limited, 1937). See Martin Höpner and Armin Schäfer, "Embeddedness and Regional Integration: Waiting for Polanyi in a Hayekian Setting," International Organization 66, no. 3 (2012): 429-55, https://doi.org/10.1017/S002081831200015X; and Wolfgang Streeck, Buying Time: The Delayed Crisis of Democratic Capitalism (New York: Verso, 2014) for analyses that similarly highlight the structural similarity between Hayek's vision of interstate federalism and the EU/EMU.
} 
when it was negotiated. Some may have ${ }^{2}$, but it is by no means clear that the various national positions were informed by uniform ideological convictions. ${ }^{3}$ Rather, the Treaty was created in response to a perceived problem that resembled that which the neoliberal theory of federalism was supposed to address: the problem of excessive (societal demands for) state intervention in economic matters. This problem was epitomised by the inability of many governments to bring inflation under control, although this was by no means the only symptom. The responsein Maastricht's EMU as in the neoliberal theory of federalism-was to strip Member States of their control of monetary policy, while subjecting fiscal practices to market discipline reinforced by rules. The response to the liberal democratic state's 'crisis of governability' was thus found in constraining the state's economic powers: the 'illusion' of the state's economic omnipotence-the idea that the state can control economic developments according to willwas to be dispelled by stripping the state of its economic omnicompetence-the idea that the state has the right to try to. This logic at the same time militated against the creation of an omnicompetent public authority-a gouvernement economique - at the supranational level.

Today, the problem of excessive public control of economic matters has largely been eclipsed by problems - market failures, sluggish growth, climate change, financial instability, public health emergencies, etc. - to which the neoliberal theory of federalism has few answers and which the original EMU was ill-equipped to deal with. More specifically, the long decade since the eruption of the Great Financial Crisis in 2007-8 has revealed that markets are unfit for ensuring sustainable public and private finances. Notwithstanding their continued prevalence in some circles, furthermore, concerns about inflationary pressures seem ever more irrelevant. Governments and central banks have been called upon to rescue banks and other companies in order to prop up and buy time for a stagnating capitalist economy. ${ }^{4}$ The massive accumulation of public debt and monetary stimulus that has resulted from such efforts,

\footnotetext{
2 Tommaso Padoa-Schioppa, "Il Federalismo Economico e La Comunità Europea," II Mulino, June 1993. In this article Padoa-Schioppa, who was an influential rapporteur on the Delors Committee, claims that "il federalismo è un sistema constituzionale che nasce dall'idea di 'governo minimo'" [federalism is a constitutional system born from the idea of 'minimal government'].

${ }^{3}$ Kenneth Dyson and Kevin Featherstone, The Road To Maastricht: Negotiating Economic and Monetary Union, The Road To Maastricht (Oxford: Oxford University Press, 1999).

${ }^{4}$ Streeck, Buying Time: The Delayed Crisis of Democratic Capitalism; Lawrence H Summers, "The Age of Secular Stagnation," Foreign Affairs 95, no. 2 (2016): 2-9.
} 
however, has not led to the runaway inflation that it is supposed to according to the economic doctrine informing both the neoliberal theory of federalism and the EMU's public law structure.

In Europe, the Financial Crisis turned into a fiscal and sovereign debt crisis for a number of EU Member States. ${ }^{5}$ As public debt grew, the problem was not inflation, but the risk of sovereign default, which increased along with the yields demanded on government bonds. For the Member States of the Eurozone, markets seemed to factor in a redenomination risk that reflected a concern about the imminent collapse of the euro and the reversion to national monetary units liable to devaluations by cash-strapped governments. Taken together, these developments constituted an existential crisis for the Eurozone and therefore, or so European elites argued, the EU. In emergency mode, the crisis was addressed through a combination of bank and Member State bailouts; unconventional monetary policies; extensive programmes of public sector and labour market reform; and draconian austerity measures. ${ }^{6}$ Collectively, such Eurozone crisis measures amounted to the establishment of an emergency political governmental apparatus that had previously been absent from the public law structure of the EU and which allowed for highly intrusive interventions by European institutions into core areas of state competence. ${ }^{7}$ Combined with the creation of new, and reform of existing, institutions, mechanisms and procedures at the European level, the Eurozone underwent a considerable constitutional transformation. ${ }^{8}$

The Eurozone's constitutional transformation in emergency mode, or so the chapter argues, constitutes a break with the neoliberal theory of federalism embodied in the original EMU. The post-crisis EMU embodies, in particular, a radically different vision of the role of public authority in economic affairs. This transformed vision reflects that the principal problem facing the Eurozone, according to political elites, is not an excess of government intervention

\footnotetext{
${ }^{5}$ For a good account of the mechanisms involved, see Adam J. Tooze, Crashed: How a Decade of Financial Crises Changed the World (London: Penguin Books, 2019) Part III in particular.

${ }^{6}$ Mark Blyth, Austerity : The History of a Dangerous Idea (Oxford: Oxford University Press, 2015); Streeck, Buying Time: The Delayed Crisis of Democratic Capitalism.

${ }^{7}$ Signe Rehling Larsen, The Theory of the Federation and the European Union (Oxford: Oxford University Press, 2021), chap. 5; Federico Fabbrini, "The Fiscal Compact, the 'Golden Rule' and the Paradox of European Federalism,” B.C. Int'l \& Comp. L. Rev36, no. 1 (2013): 1-38.

${ }^{8}$ See, e.g., Christian Joerges, "The European Economic Constitution and Its Transformation Through the Financial Crisis," in A Companion to European Union Law and International Law, ed. Dennis Patterson and Anna Södersten (Malden, MA \& Oxford: John Wiley \& Sons, Ltd, 2016), 242-61; Agustín José Menéndez, “Editorial: A European Union in Constitutional Mutation?," European Law Journal20, no. 2 (2014): 127-41.
} 
but governmental impotence. The primary concern, therefore, is not to stifle but to generate governmental capacity. However, the new EMU does not revert back to the pre-EMU order of economic government. It seeks, rather, to make the Eurozone governable by strengthening governmental capacity at the European level. This vision deemphasises structure and process (and specific laws for that matter) in favour achieving specific outcomes through the active use of (authoritarian, coercive) public authority.

The outcomes pursued during the Eurozone Crisis were largely those traditionally associated with neoliberalism. In this sense, the EMU's transformation can be seen as an extension and intensification of the EMU's neoliberal foundations. ${ }^{9}$ This chapter highlights, however, that while neoliberal policy reforms may have been the primary outcome so far, the public law framework of the EMU no longer expresses a neoliberal vision of economic government. The main reason for this is that the reformed EMU provides means for employing governmental powers actively to produce certain politically desired outcomes. In place of 'impersonal,' apolitical mechanisms (markets and rules in particular), the new EMU employs public power and discretion to realise its aims. This opens up the possibility of employing the newly generated governmental capacity for outcomes other than those associated with neoliberalism. In concluding, the chapter notes that the early response to the Covid-19 Crisis attests to this possibility. This highlights that the public law framework is not ideologically neutral. It always organises the exercise of governmental power in a particularway that makes certain ways of acting possible and others impossible.

\section{The Maastricht Constitutional Imaginary}

The Eurozone's constitutional construction, as originally outlined in the Maastricht Treaty, entrenches a distinction-conceptual, temporal and practical-between the authorisation of governmental powers and the exercise of those powers. In short, the EMU rests on the notion that the exercise of governmental authority is based on a founding act, a "democratic naissance."10 This founding act establishes a comprehensive public law framework that

\footnotetext{
${ }^{9}$ See, e.g., Michael A. Wilkinson, "Authoritarian Liberalism in Europe: A Common Critique of Neoliberalism and Ordoliberalism," Critical Sociology 45, no. 7-8 (2019): 1023-34, https://doi.org/10.1177/0896920519837325; and Ian Bruff, "The Rise of Authoritarian Neoliberalism," Rethinking Marxism 26, no. 1 (2014): 113-29, https://doi.org/10.1080/08935696.2013.843250.
}

${ }^{10}$ Chiara Zilioli and Martin Selmayr, The Law of the European Central Bank(Oxford: Hart, 2001), 49. 
organises the exercise of governmental powers concerning economic policy at both the main governmental levels of the Eurozone-the Member State and the European. ${ }^{11}$ While entirely elite driven, the EMU's creation was attributed to the will of the European peoples as the fundamental political subjects of their respective Member States and thus, collectively, of the EU. ${ }^{12}$ In its constitutional imaginary, then, a free agreement between, and expression of, the Member State peoples' political wills constitutes the foundation of the governmental order established by the Maastricht Treaty. As the European Central Bank (ECB) conceptualises its own foundation of authority:

It was the sovereign decision of the peoples of Europe (through their elected representatives) to transfer the competency for monetary policy and the other tasks enumerated in the Treaty to a newly created European body, and to endow it with independence from political interference. ${ }^{13}$

While the ECB refers only to itself in the quote above, the logic applies to the EMU as a whole. However, even though a unified expression of political will may form the foundation of the EMU's governmental order, the founding act only to a very limited extent established institutional mechanisms through which the wills of the several peoples could be merged into one that continuously informed the means and ends of economic government. The EMU did not, in other words, create one or more political institutions that had the right to govern it in its entirety. The distinction between, and constitutional separation of, the 'fiscal' and 'monetary' dimensions of economic policy in the EMU's public law framework reflects this.

Separating the right to conduct monetary policy from the right to conduct fiscal policy makes it impossible for any one authority to control all the main levers of macroeconomic policymaking. No authority is omnicompetent when it comes to economic policy. While many commentators in academia and beyond have highlighted that this arrangement makes the EMU dysfunctional in certain respects, the absence of a transfer of general economic policymaking competences to a European authority unquestionably made the very idea of the union more

\footnotetext{
11 David H McKay, Federalism and European Union : A Political Economy Perspective. (Oxford: Oxford University Press, 1999); Larsen, The Theory of the Federation and the European Union.

12 Dieter Grimm, "Sovereignty in the European Union," in Constitutional Sovereignty and Social Solidarity in Europe, ed. Johan Van der Walt and Jeffrey Ellsworth (London: Bloomsbury/Nomos, 2015), 39-54, 48; Miguel Poiares Maduro, “Opinion of Advocate General Poiares Maduro in Kadi” (CJEU, January 16, 2008), 21.

${ }^{13}$ European Central Bank, “The Accountability of the ECB,” ECB Monthly Bulletin, no. November (2002): 45-57, 46.
} 
palatable at the time to political forces jealous of national sovereignty. In this way, Member States could retain important economic competences and the transfer of sovereign powers would appear less intrusive. That the arrangement contributed to the political feasibility of the Union, however, does not mean that it is not ideologically informed, only that a particular ideological perspective was amenable to the interests of key actors. ${ }^{14}$ However that may be, and whether the product of a grand design or not, the absence of an omnicompetent governmental authority gives constitutional expression to the Hayekian notion of the dangers associated with 'the pretence of knowledge' in economic policymaking. ${ }^{15}$ Referring to the impossibility of predicting the full consequences of any governmental action, this perspectives sees the illusion of government omnipotence as the source of ever more intrusive, and ever more ineffective, public interventions in economic matters: any intervention or adjustment creates the need for further interventions to correct the unintended effects of foregoing interventions, and so on down the 'road to serfdom.'

As discussed towards the end of this section, the Stagflation Crisis of the 1970s was to a large extent interpreted as confirmation of this thesis and of the need for governmental restraint in order to overcome it. The neoliberal theory of interstate federalism, formulated long before this crisis arose, offered a compelling route to ensuring such restraint. Before discussing the main tenets of this theory, however, a few notes on the original EMU's public law framework and its constitutional separation of monetary and fiscal competences are in order.

\section{The Maastricht Constitutional Structure}

The central structural feature of the EMU's monetary dimension is the ECB's independence in conducting monetary policy (article 130 TFEU). Established by the treaty, the ECB's independence is based on primary law. This means that its institutional form as well as its governmental acts are beyond the control of any constituted body of ordinary political representatives. ${ }^{16}$ As such, the ECB's authority does not rest on present electoral majorities or

\footnotetext{
${ }^{14}$ McKay, Federalism and European Union: A Political Economy Perspective, 76-85. Conversely, the ideological perspective informing the 1970 Werner Report's vision of economic and monetary union-which foresaw full political union, including a European economic government accountable to the European Parliament-was not.

${ }^{15}$ Friedrich A Hayek, "The Pretence of Knowledge” (Nobel Lecture, Sveriges Riksbank's Prize in Economic Sciences in Memory of Alfred Nobel, Stockholm, Sweden, 1974), https://www.nobelprize.org/prizes/economicsciences/1974/hayek/lecture/.

${ }^{16}$ Whether its monetary policy acts are also beyond judicial control is a question of considerable controversy, as the evolving saga of the Gauweiler and Weiss cases attests to. See also Vestert Borger, "Central Bank
} 
other ways of expressing political will in the present. The ECB's authority rests, in principle, on the founding expression of political will in the Maastricht Treaty. Since the Maastricht Treaty was created by the Member States peoples as distinct political subjects, any violation of this principle-say, by allowing the European Parliament to control any aspect of the ECB's exercise of powers-would threaten the continued existence of the Member State peoples as separate political subjects. This is because it would alter the subject of the highest political authority from the peoples as separate political subjects acting collectively, to a unitary subject acting unilaterally. ${ }^{17}$ As such, the absence of meaningful democratic accountability with respect to the $\mathrm{ECB}^{18}$ is an essential element in protecting the original expression of political will by the peoples as well as a protection of the peoples as separate political existences. While its authority is politically established, the institutional structure leaves no room for its political control at either the European or the Member State level.

The absence of democratic controls over the ECB is justified within the EMU's constitutional imaginary by the notion that central bank independence is essentially another word for the single-minded pursuit of price stability, the primacy of which is the monetary dimension's central substantive feature (article 3.3 TEU; article 119.2, 127.1 TFEU). The price stability anchor is, on the one hand, a justification for the ECB's independence, as the EMU rests on the theory that central bank independence is the surest means of securing price stability. Central bank independence is simply the institutional expression of the aim of price stability. On the other hand, the price stability mandate constitutes a means of constraining the ECB's discretion because it is not allowed to exercise its governmental authority in a manner that jeopardizes this objective. ${ }^{19}$ The ECB can only, in principle, act for purposes other than securing price stability if this does not compromise the price stability mandate. Thus, if the ECB's

\footnotetext{
Independence, Discretion, and Judicial Review," in EU Executive Discretion and the Limits of Law, ed. Joana Mendes (Oxford: Oxford University Press, 2019), 118-31.

17 This is the essence of the German Constitutional Court's 'no demos' thesis, which also informs its jurisprudence on questions relating to the ECB in cases such as Brunner, OMTand PSPP. For a discussion of this principle in relation to the ECB's handling of the Eurozone Crisis, see Hjalte Lokdam, "We Serve the People of Europe': Reimagining the ECB's Political Master in the Wake of Its Emergency Politics," JCMS: Journal of Common Market Studies 58, no. 4 (2020): 978-98.

18 See, e.g., René Smits, The European Central Bank - Institutional Aspects (The Hague: Kluwer Law International, 1997), 500; Deirdre Curtin, “'Accountable Independence' of the European Central Bank : Seeing the Logics of Transparency," European Law Journal 23 (2017): 28-44.

${ }^{19}$ See Otmar Issing, Should We Have Faith in Central Banks?(London: The Institute of Economic Affairs, 2002); Borger, "Central Bank Independence, Discretion, and Judicial Review."
} 
independence from all other governmental bodies (including European ones) is a means of depoliticising the conduct of monetary policy, the price stability mandate is intended to secure that the ECB itself does not become 'political' itself in the sense of choosing between competing objectives. The key aspect of the monetary dimension of the EMU is thus to abolish the competence to control one variable of macroeconomic policymaking discretionarily, whether by the central bank or political authorities.

The fiscal dimension of the Maastricht EMU took a very different constitutional form. Instead of a single fiscal authority, fiscal responsibility remained with the Member States. The crucial structural feature of the fiscal dimension is thus a decentralisation (or the absence of a centralisation) of governmental authority. Whereas the monetary dimension concentrates governmental power in a single, politically independent authority, the fiscal dimension disperses it among several political authorities: the Member State parliaments and governments. This entailed that the control of taxes, public spending and other aspects of economic policy was to remain subject to the political process in the individual Member States. As much a product of the Treaties as the ECB's independence and price stability mandate, this is attributed to the political will of the peoples. In contrast to the monetary dimension, then, the right of the Member States' political authorities to define the ends and means of governmental action with regard to fiscal policy was not exhausted in the constituent moment. The Eurozone's monetary policy would be conducted in the singular and beyond the control of democratic majorities, but fiscal policies remain plural and subject to the electoral majorities of the day in the respective Member States.

As discussed in more detail below, the continued existence of fiscal competences at the Member State level is crucial to the neoliberal theory of interstate federalism. It entails a certain political freedom at the Member State level that secures that the federation does not become a great Leviathan but is instead characterised by interstate competition for capital and labour. The EMU, according to the Delors Report, had to respect the "existence and preservation of [Member State] plurality" and the Member States should therefore retain "a degree of autonomy in economic decision-making." 20 Structurally, in other words, the Member States remained competent to adopt more or less whatever fiscal policy they saw fit. The Maastricht

\footnotetext{
${ }^{20}$ Delors Report, "Report on Economic and Monetary Union in the European Community 17 April. Brussels: EC
} Commission." (EC Commission, April 17, 1989), 13 (emphasis in original). 
Treaty, however, also outlined a set of general, substantive aims for fiscal policy—including a number of fiscal conditions and requirements ('convergence criteria') later elaborated in the Stability and Growth Pact-that were to ensure the basic fiscal homogeneity necessary to ensure a viable monetary union geared towards price stability. ${ }^{21}$ The economic policy discretion of Member States was thereby to be subjected to certain self-imposed but externalised limits. ${ }^{22}$

The principle of Member State responsibility for fiscal policy was reinforced by a number of specific prohibitions contained in the Treaty, most notably the ban on monetary financing of Member States by the ECB (article 123 TFEU) and the no-bailout clause (article 125 TFEU). The intended effect of these bans was to ensure that Member States' fiscal freedom remained subject to market discipline: while any kind of fiscal policy was in principle possible, it had to be financed through the state's ability to extract taxes from freely mobile capital and labour and/or from borrowing on market terms. ${ }^{23}$ The discretion left to Member State governments should not, in other words, allow them to collectivise the potential costs of 'irresponsible' policies. This also meant that the feasibility of a particular economic programme was subject to market evaluation. The constraint on the economic policymaking capacity of the Member States was thereby not primarily a product of the legal regulation of the specific content of policies. In terms of normative content, the EMU is all but silent. ${ }^{24}$ Rather, the EMU public law framework envisioned a reckoning between Member State economic policies, including their aims and financing, and the confidence of markets.

\footnotetext{
${ }^{21}$ The economic case for the necessity of convergence criteria and fiscal rules is questionable. On this, see Paul De Grauwe, "Monetary Union and Convergence Economics," Papers and Proceedings of the Tenth Annual Congress of the European Economic Association 40, no. 3 (April 1, 1996): 1091-1101; Paul De Grauwe, Economics of Monetary Union, 13th ed. (Oxford: Oxford University Press, 2020), ch. 11. So is the case for the necessity of relative economic homogeneity once the monetary union is established, see Waltraud Schelkle, The Political Economy of Monetary Solidarity : Understanding the Euro Experiment (Oxford: Oxford University Press, 2017). However, as Schelkle (p.1) notes, heterogeneity may spark a mistrust and lack of understanding between the diverse parties that makes collective action in terms of risk sharing more difficult. Whether this is enough to account for Europe's preoccupation with convergence is unclear.

${ }^{22}$ Self-imposed because the Member States themselves signed up for them; externalised because the limits were enshrined in a legal framework beyond the control of the political authorities of any one Member State.

${ }^{23}$ Alexandre Lamfalussy, "Macro-Coordination of Fiscal Policies in Economic and Monetary Union in Europe," in Collection of Papers Submitted to the Committee for the Study of Economic and Monetary Union (Luxembourg: Office for Official Publications of the European Communities, 1989), 91-126.
}

${ }^{24}$ Clemens Kaupa, The Pluralist Character of the European Economic Constitution (Oxford: Hart, 2016). 


\section{The Neoliberal Theory of Interstate Federalism}

The combination of a politically independent monetary policy, the absence of a single fiscal authority, and subjecting Member State fiscal policy to market discipline in many ways formed the macroeconomic constitutional superstructure to the 'microeconomic constitution' of the single market. ${ }^{25}$ An understanding of the consequences of EMU in terms of general governmental capacity with respect to economic affairs therefore demands an appreciation of the link between the micro- and macroeconomic elements of the general 'economic constitution.'26 This link is central to the neoliberal theory of federalism. As Hayek put it in "The Economic Conditions of Interstate Federalism":

The absence of tariff walls and the free movements of men and capital between the states of the federation has certain important consequences ... They limit to a great extent the scope of the economic policy of the individual states. If goods, men, and money can move freely over the interstate frontiers, it becomes clearly impossible to affect the prices of the different products through action by the individual state. The Union becomes one single market. 27

This is, in essence, a description of 'negative integration.' According Hayek, this mechanism emerges from the structural characteristics of an economic federation that involves the creation of a customs union and a single market: "the federation will have to possess the negative power of preventing individual states from interfering with economic activity in certain ways." ${ }^{28}$ In the EU, negative integration may find its agency in the judicial activism of

\footnotetext{
${ }^{25}$ Kaarlo Tuori, European Constitutionalism, Cambridge Studies in European Law and Policy (Cambridge: Cambridge University Press, 2015), https://doi.org/10.1017/CB09781316091883.

26 This is a key aspect of Fritz Scharpf's work on the neoliberalising consequences of 'negative integration' in a political structure that makes 'positive integration' slow, cumbersome and subject to multiple veto players (see e.g., Fritz W. Scharpf, "After the Crash: A Perspective on Multilevel European Democracy," European Law Journal 21, no. 3 (2015): 384-405; Fritz W. Scharpf, Governing in Europe: Effective and Democratic?(Oxford: Oxford University Press, 1999).

${ }^{27}$ Friedrich A Hayek, "The Economic Conditions of Interstate Federalism," in Individualism and Economic Order (Chicago, IL: The University of Chicago Press, 1948 [1939]), 255-72, 258. The logic informing this is that associated with jurisdictional or regulatory arbitrage, which predicts a taxational and regulatory 'race to the bottom' within a single market of several otherwise independent jurisdictions. Under such conditions, states are less able to effectively introduce tax policies or regulatory regimes that place onerous demands on individuals or firms because of the freedom of movement. As such, the tendency is towards a form of government that is less intrusive in the economic lives of its citizens, natural and artificial, not because of conviction but because intervention is simply counter-productive.
}

${ }^{28}$ Hayek, 267, emphasis added. 
the European Court of Justice, as scholars such as Fritz Scharpf have argued ${ }^{29}$, but the mechanism itself, according to the neoliberal theory of federalism, is built into the very structure of economic integration based around the principle of open, competitive markets. This mechanism limits the individual state's capacity to effectively control economic activity within its border (including through taxation because people, firms and capital can relocate) and curtailing the power of organised interests within the state. ${ }^{30}$ Through the interlinkages between the micro- and macroeconomic dimensions of the constitutional frameworks, the interstate federation limits the governmental capacity of the individual state when it comes to economic activity.

As Hayek emphasises, the powers denied the individual states can only to a limited extent be transferred to the federal level. On the one hand, this is because the federation implies the continued existence of the constituent states as autonomous entities, not the creation of a sovereign federal state whose authority can override that of the states. The federal level, however, can act on a common agreement among the constituent states. As such, nothing prevents it from adopting whatever policy the states agree to. The problem is to reach agreement. The limited power of the federation is thus not a necessary principle of federalism but a consequence of the interaction between the public law structure of the federation and the 'material constitutions' 31 of its constituent parts. As Hayek notes, "Whether the federation will exercise these powers [of governmental intervention in economic activity] will depend on the possibility of reaching true agreement, not only on whether these powers are to be used, but on how they are to be used." 32 In principle, then, the federation's governmental capacity is open-ended and there can be "ample scope for economic policy in a federation ... there is no need for extreme laissez faire in economic matters". ${ }^{33}$ However,

\footnotetext{
${ }^{29}$ Scharpf, Governing in Europe, ch. 2.

${ }^{30}$ Hayek, "The Economic Conditions of Interstate Federalism," 261, see also Poul F. Kjaer, "The Transnational Constitution of Europe's Social Market Economies: A Question of Constitutional Imbalances?," JCMS: Journal of Common Market Studies 57, no. 1 (January 1, 2019): 143-58, who highlights that European integration has to a large extent strengthened the state vis-à-vis corporate interests within the state.

${ }^{31}$ Marco Goldoni and Michael A. Wilkinson, "The Material Constitution," The Modern Law Review 81, no. 4 (2018): 567-97, https://doi.org/10.1111/1468-2230.12352.
}

32 Hayek, "The Economic Conditions of Interstate Federalism," 266.

33 Hayek, 268; see also Kaupa, The Pluralist Character of the European Economic Constitution, for an analysis of the EU that stresses this point. 
the degree to which planning [or central direction of economic activity] can be carried is limited to the extent to which agreement on ... a common scale of values can be obtained or enforced. It is clear that such agreement will be limited in inverse proportion to the homogeneity and the similarity in outlook and traditions possessed by the inhabitants of an area. ${ }^{34}$

Reaching an agreement on how to employ governmental powers to control economic activity thus, according to Hayek, represents a tall order for federations. This is because a federation cannot to the same extent as the nation state rely on "common ideals and common values." 35 It cannot, in other words, rely on the national myths and ideologies that justify the sacrifice of the interests of some members of the community in the name of the national good. ${ }^{36}$ Thus, the "diversity of conditions and the different stages of economic development reached in the various parts of the federation will raise serious obstacles to federal legislation."37

An interstate federation whose two most important structural features are a single market and a single currency ${ }^{38}$ thereby promises to limit significantly the scope of governmental capacity to intervene in and govern economic affairs at both the state and federal levels. The public law structure of the federation thereby implies "less government all round if federation is to be practicable" and "we shall have to resign ourselves rather to have no legislation in a particular field than the state legislation which would break up the economic unity of the federation." 39 In that sense the federation introduces a governmental order of relative laissez faire: while its does not dismantle existing programmes of market intervention in one stroke, it constrains the general governmental capacity of the states to respond to socioeconomic developments as they arise, without generating a corresponding Union level governmental capacity. ${ }^{40}$ While the constitution may not explicitly provide for neoliberal policies (privatisation, deregulation, labour flexibilisation, etc.) or create an outright laissez

\footnotetext{
${ }^{34}$ Hayek, "The Economic Conditions of Interstate Federalism," 264.

35 Hayek, 264.

${ }^{36}$ Hayek, 262.

${ }^{37}$ Hayek, 263.

${ }^{38}$ Hayek, "The Economic Conditions of Interstate Federalism," 259-60.

${ }^{39}$ Hayek, 266.

${ }^{40}$ Scharpf, Governing in Europe; on this process in history of the US, see Gary Gerstle, Liberty and Coercion: The Paradox of American Government from the Founding to the Present (Princeton, NJ: Princeton University Press, 2017).
} 
faire order, it orients the exercise of governmental authority in a manner that facilitates the gradual impossibility of effectively intervening in economic life.

By abolishing omnicompetent political authority, the federation dispels the illusion of the state's omnipotence that, from a neoliberal perspective, haunted economic policymaking from the end of $19^{\text {th }}$ century laissez faire. It does so explicitly by depriving Member States of the formal competence to control monetary policy-which introduces an external condition and constraint over which individual governments have no control—and implicitly through the single market-which facilitates 'voting with your feet' and, more importantly, 'voting with your capital.' ${ }^{41}$ Such constraints in effect mean that while the Member States retain political freedom with regard to what economic policies to adopt, the effectiveness of any policy depends on market actors' perception of it. The potency of governmental power at the state level is, in other words, undercut by the federal structure. At the same time, governmental capacity at the federal level, while potentially potent vis-à-vis markets, is neutered by the difficulty of reaching 'true agreement' among the several States. That is, because the federation does not establish a new omnicompetent, sovereign entity, the principal 'danger' associated with 'the illusion of omnipotence' is overcome and sovereignty is 'eroded.' 42 Through alienating the governmental capacity to 'steer the economy,' the interventionist state of fascism and communism, but also of social democracy and progressivism ${ }^{43}$, would become impossible. The 'proper' distinction between state and society, the political and the economic, would thereby be (re)established. As Wilhelm Röke put it in the context of the debate on European economic integration:

little would be gained, if the sovereign right, which today the governments invoke to intervene in economic life, were taken away from them solely for the purpose of transferring it to an international authority ... Certainly the lessening of national sovereignty is one of the most compelling commands of

\footnotetext{
41 On the notion of 'voting with your capital,' see Streeck, Buying Time: The Delayed Crisis of Democratic Capitalism, 80-90.

42 Martin Loughlin, “The Erosion of Sovereignty," Netherlands Journal of Legal Philosophy 2 (2016): 57-81; see also Markus Ojala, "Doing Away with the Sovereign: Neoliberalism and the Promotion of Market Discipline in European Economic Governance," New Political Economy, February 20, 2020, 1-13, https://doi.org/10.1080/13563467.2020.1729714.

43 Sheri Berman, The Primacy of Politics: Social Democracy and the Making of Europe's Twentieth Century (Cambridge: Cambridge University Press, 2006).
} 
our time, but the excess of sovereignty should be abolished and not transferred to a higher geographical unit. ${ }^{44}$

The EMU reflected the neoliberal logic of federalism in that the transfer of "sovereignty with regard to monetary policy to the Eurosystem" 45 would not be emulated with respect to other dimensions of economic policy. As Karl Otto Pöhl, then president of the Bundesbank, put it in the context of the Maastricht negotiations: EMU would "necessitate the surrender of sovereignty by the individual member states, but this need not mean corresponding gains in Community authority." 46 Through a founding expression of political will by the Member State peoples, the EMU would break the link between the generation of societal demands on the state through the political process and the governmental capacity to act on such demands that allowed for large-scale political control of economic activity from the interwar period and into the 1970s.

\section{The Crisis of Governability and the EMU}

While the federalism adopted by the framers of the Maastricht Treaty mirrors the neoliberal image of limited government through interstate federalism, this alone can hardly account for why it was adopted. While it is not the ambition of this chapter to explain why the EMU was created as it was, it is worth stressing one important problem that it was intended to address: the problem of governmental 'overload' or 'crisis of governability' that Western democracies, including but not limited to the European, were (perceived to be) experiencing in the 1970s and 80 s. ${ }^{47}$ It was this crisis, whose greatest symptom was the Stagflation Crisis, that increased

\footnotetext{
${ }^{44}$ Röpke, International Order and Economic Integration, 108 (emphasis in original).

${ }^{45}$ European Central Bank, "The Institutional Framework of the European System of Central Banks," ECB Monthly Bulletin July (1999): 55-63, 55.

${ }^{46}$ Karl Otto Pöhl, "Herr Pöhl Discusses the Basic Features of a European Monetary Order" (Speech in Paris, January 16, 1990), TPS-193, Historical Archives of the European Union.

${ }^{47}$ See, e.g., Michael J. Crozier, Samuel P. Huntington, and Joji Watanuki, The Crisis of Democracy: Report On the Governability of Democracies to the Trilateral Commission (New York: New York University Press., 1975); Anthony King, "Overload: Problems of Governing in the 1970s," Political Studies 23, no. 2 \& 3 (1975): 284-96. Hayek's 1939 case for an interstate federation drew on a similar analysis: "Government by agreement is only possible provided that we do not require the government to act in fields other than those in which we can obtain true agreement. If, in the international sphere, democratic government should only prove to be possible if the tasks of the international government are limited to an essentially liberal program, it would no more than confirm the experience in the national sphere, in which it is daily becoming more obvious that democracy will work only if we do not overload it and if the majorities do not abuse their power of interfering with individual freedom. Yet, if the price we have to pay for an international democratic government is the restriction of the power and scope of government, it is surely not too high a price" (p 271).
} 
the appeal of the neoliberal worldview in general among political elites, with Ronald Reagan and Margaret Thatcher, of course, its principal political champions. It seemed to confirm the neoliberal thesis that governments are essentially constrained by economic laws and that the failure to recognise these constraints a priori can only lead to ever more coercive, but ineffective, governmental interventions to address the destructive effects of earlier policies. On the European continent, the travails and, ultimately, ideological capitulation of President Mitterand's Socialist government in France in the first half of the 1980s seemed to hammer this point home: economic planning and the state's steering of economic affairs was doomed to fail.

Disregarding the question of the accuracy of this interpretation, the notion of a 'crisis of governability' reflected a concern among political elites (and scholars) at the time that electorates and interest groups placed increasingly unsustainable, and often contradictory, demands on the state. Democratic politics, it seemed, placed an "excessive burden ... on the 'sharing out' function of government," understood as "the activities of public authorities in influencing the allocation of resources, both through taxation and expenditure policies and through direct intervention in the market place." 48 The state, in other words, was asked to do more than it was able to accomplish effectively. This was tied to the perception that the Keynesian instruments of economic government, on which most capitalist democracies had to some extent relied on since the end of World War II, were no longer working as intended, and as they had done in les Trente Glorieuses. As the Post-Keynesian economist Wallace C. Peterson noted in 1980,

What is clear from the experience of the last decade is that the conventional Keynesian approach is not working, that we are confronted with a condition which does not respond to the standard techniques which use fiscal and monetary policies for demand management. 49

The failure of governmental capacity was epitomised by the failure of many Western states to control inflation, which in turn was seen as being to a significant extent a product of the democratic political process itself. 50 While this was by no means the only problem, it

\footnotetext{
48 Samuel Brittan, "The Economic Contradictions of Democracy," British Journal of Political Science 5, no. 2 (1975): 129-59, 130 (emphasis removed).

49 Wallace C. Peterson, “Stagflation and the Crisis of Capitalism,” Review of Social Economy 38, no. 3 (1980): 277.

50 See, e.g., Samuel Brittan, "Inflation and Democracy," in The Political Economy of Inflation, ed. Ruth Hirsch and John H. Goldthorpe (Cambridge, MA: Harvard University Press, 1978), 161-85; Alberto Alesina,

"Macroeconomics and Politics," NBER Macroeconomics Annual3 (1988): 13-52.
} 
provided a powerful image of there being economic mechanisms operating outside the control of national governments. In doing so, it appeared to confirm Hayek's suspicion of the 'pretence of knowledge': it illustrated that the total effects of any policy were beyond the control of the policymaker. As such, it seemed to confirm the neoliberal vision of economic government: even in the absence of formal constraints on governmental capacity, this capacity is always already constrained by economic laws operating beyond the control of political authorities. ${ }^{51}$

On the one hand was thus a concern that political demands had become excessive and, on the other, that the capacity of the state to deliver on those demands was waning. Together these two trends were seen as a threat to the credibility and viability of liberal democracy. ${ }^{52}$ In order to rescue liberal democracy from itself, and thus the capitalist economy, it was therefore necessary to introduce a dual constraint: on the people's ability to demand things of the state and on the governmental capacity of the state to intervene in economic matters. A form of macroeconomic federalism that reduced state capacity through depriving governments of the control of monetary policy combined with legally enforced market discipline on fiscal practices promised to overcome this quagmire. The problem that EMU was designed to address, in other words, was how to reconstitute the European states in a manner that forced them to govern in accordance with the 'natural' constraints of the economic order of things. ${ }^{53}$ Rather establishing a 'neoliberal sovereign' that could coerce the Member States into compliance, the EMU sought to create an order in which the states would retain political freedom to decide on the distribution of public spending but subject to the same kind of budget constraint as households. ${ }^{54}$ As a draft of the Delors Report put it, "all member countries will have to recognise

\footnotetext{
51 This was the conservative interpretation of the crisis. See Wolfgang Streeck, Buying Time: The Delayed Crisis of Democratic Capitalism, (New York: Verso, 2014) for a discussion of the more leftists interpretation of the crisis at the time, which attribute the crisis to capitalism, not democracy.

${ }^{52}$ Crozier, Huntington, and Watanuki, The Crisis of Democracy.

${ }^{53}$ Michel Foucault, The Birth of Biopolitics. Lectures at the Collège de France, 1978-1979(London: Palgrave Macmillan, 2008); Werner Bonefeld, The Strong State and the Free Economy (London: Rowman \& Littlefield International, 2017). See also Wilhelm Röpke, International Order and Economic Integration (DordrechtHolland: D. Reidel Publishing Company, 1959), 75, who presents the "liberal principle" as being "a thorough separation between the spheres of the government and of economy, between sovereignty and the apparatus which provides material goods." Röpke thereby considers political and economic power to be distinct forms of power, corresponding to the Roman distinction between Imperium (public command associated above all with military affairs) and Dominium (control and disposition of private property above all in the household). Concentrating the two forms of power, he argues, the centralised, sovereign state tends to become 'total' and societal life becomes unfree.

${ }^{54}$ William Mitchell and Thomas Fazi, Reclaiming the State: A Progressive Vision of Sovereignty for a PostNeoliberal World (London: Pluto Press, 2017).
} 
and accept in their decision-making the existence of the constraints on national fiscal policy that emanate from participation in an economic [and] monetary union." 55 The state's political freedom to act 'irrationally' and ignore the limits of its means was thus to be eliminated and with it its ability to act on the demands emerging from the democratic process. The state's ability to govern 'excessively' had to be abolished.

\section{The Challenge of the Eurozone Crisis}

The EMU sought to respond to the crisis of governability by depriving Member State governments of the access to the printing press to finance their deficit spending, on the one hand, and by subjecting fiscal policy to market discipline reinforced by fiscal rules, on the other. Combined with the 'microeconomic constitution' of the single market, this was supposed to ensure that Member States were forced to recognise, and govern in accordance with, the immanent laws of the economy. While the neoliberal imaginary sees these laws operating irrepressibly beyond the control of political forces, and irrespective of any legal framework, the constraints that Eurozone Member States faced in terms of economic policy were nevertheless politically established and self-imposed. As such, the effectiveness of the order relies on continued political support for it. This, of course, is one of the central tensions, and perhaps the greatest weakness, of the neoliberal imaginary: the 'natural' order of the market economy relies on a politically established legal framework and a continued political will in its favour. 56 The problem of governmental capacity with respect to economic government, then, re-emerges if one or more Member States reject the basic tenets of the order whether in practice or principle. As long as the Member States retain the political freedom to (try to) ignore the constraints inherent in the structure, the problem of 'excessive government' remains.

This problem is avoided if markets actually perform a disciplining function in the sense of punishing certain forms of state behaviour. If markets fail to do so, the neoliberal theory of

\footnotetext{
55 Committee for the Study of Economic and Monetary Union (CSEMU), "II. How to define the final stage of economic and monetary union," p. 2, 31 January 1989, draft of chapter 2 of Delors Report, Historical Archives of the European Union (HAEU), TPS-196.

56 This is, in fact, explicitly recognised by neoliberal thinkers such as Henry Simons, Milton Friedman and Hayek, all of whom recognise that the realisation of their world-view rests on winning "the great struggle of ideas," as Hayek put it in The Constitution of Liberty (Chicago: University of Chicago Press, 2011), 48. The German ordoliberals similarly saw the competitive market economy as resting on a 'comprehensive decision' on an economic constitution (Walter Eucken, Franz Böhm, and Hans Großman-Doerth, "Unsere Aufgabe: Geleitwort Der Herausgeber Zur Schreifenreihe," in Die Ordnung Der Wirtschaft, by Franz Böhm (Stuttgart: Kohlhammer, 1937), VII-XXI.).
} 
federalism is left with the problem of how to ensure that markets behave as they should. This is a general problem for neoliberalism, but it takes on a particular meaning in the federation, to which the framers of the Maastricht EMU were sensitive. The problem is that regardless of what the Treaty might say, "the closer economic and solidarity ties implied by membership of the union may generate market expectations that [a Member State] would ultimately be bailed out by other EMU members." 57 The very existence of the federation might, in other words, increase the ability of the individual state to govern 'excessively' because the market would operate on an assumption of 'solidarity,' whereby it would cease to evaluate the fiscal position and economic policy stance of a Member States on its own terms. Paradoxically, then, the market discipline that was supposed to have been supported by the EMU's constitutional structure would potentially be undermined by that very structure, thereby enabling Member States to evade the constraints that were supposed to result from the federal structure.

Developments after the introduction of the euro largely bore out this scenario. Sovereign bond yields converged in the years leading up to the crisis, without this necessarily reflecting actual economic convergence or equally sustainable fiscal positions. When the crisis hit, furthermore, it turned out that the markets had been right to assume solidarity: Member States were bailed out with minimal losses to investors. The Eurozone Crisis thereby demonstrated that the problem of governability was not adequately addressed by the federal construct. Demands on the state arising from domestic political processes and interest groups continued to inform the economic practices of the states to a significant degree. The federation had not resolved this 'problem' of governmental capacity at the state level. The federal construct did 'work,' however, in terms of constraining the governmental capacity of the Union level: the Union had only very limited means of correcting the behaviour of its Member States. This resulted in a different kind of governability problem. In place of a general problem of excessive government, the problem was the inability of the federal level to ensure that the Member States conformed to the requirements of the EMU construct. What emerged, in other words, was, a problem of generating the federal governmental authority necessary to make the Eurozone as a whole behave as the theory envisioned. The problem was to make the Eurozone governable

57 C.E.V. Borio, "Macro-co-ordination of fiscal policies in an economic and monetary union in Europe," appendix II, p. 13, 1 February 1989. HAEU, TPS-196. Paper submitted for discussion in the Delors Committee. See also Lamfalussy, A. "The need for co-ordination of fiscal policies in a European Economic and Monetary Union," p. 1, 31 January 1989. HAEU, TPS-196. 
in order to enforce the constraints on governmental discretion that the EMU was supposed to have ensured structurally, according to the neoliberal imaginary informing the Maastricht Treaty.

In the emergency politics of addressing the multiple failures of the EMU during the Eurozone Crisis, crucial aspects of both the structural and substantive dimensions of E(M)U law were abandoned. ${ }^{58}$ In place of rules and market discipline stepped the (authoritarian, coercive) exercise of public power to achieve the outcomes that were supposed to have emerged more or less spontaneously from the constitutional structure. ${ }^{59}$ That is, the concrete policy outcomes associated with neoliberalism-privatisation, fiscal consolidation, deregulation, labour market flexibilization, etc.-were pursued using means that differed markedly from those associated with the neoliberal theory of interstate federation. Public authority at the European level, in other words, stepped in to ensure the withdrawal of the state from the control of economic activity that market discipline had failed to bring about. The question is what vision of economic government emerges from the emergency politics of the Eurozone Crisis.

\section{Governing the Member States in Emergency Mode}

In Hayek's theory of federalism, one of the crucial limits on the governmental capacity of the federal level is the heterogeneity of the constituent parts. As long as a plurality of economic conditions and values exists within the federation, it will inevitably be more difficult to agree on the active use of federal power to regulate economic affairs. The experience of the Eurozone to large extent bears this thesis out, as Martin Höpner and Amin Schäfer have argued. ${ }^{60}$ Despite 'convergence criteria', the Eurozone economies have remained structurally distinct from each other in a number of important ways and have evolved around different varieties of capitalism

\footnotetext{
58 Thomas Beukers, Bruno de Witte, and Claire Kilpatrick, eds., Constitutional Change through Euro-Crisis Law (Cambridge: Cambridge University Press, 2017); Jonathan White, “Emergency Europe,” Political Studies 63, no. 2 (2015): 300-318.

${ }^{59}$ Alexander Somek, "Delegation and Authority: Authoritarian Liberalism Today," European Law Journal 21, no. 3 (2015): 340-60; Streeck, Buying Time: The Delayed Crisis of Democratic Capitalism; Michael Wilkinson, "Authoritarian Liberalism: The Conjuncture behind the Crisis," in The Crisis behind the Eurocrisis: The Eurocrisis as a Multidimensional Systemic Crisis of the EU (Cambridge: Cambridge University Press, 2019), 101-21.

${ }^{60}$ Höpner and Schäfer, "Embeddedness and Regional Integration: Waiting for Polanyi in a Hayekian Setting."
} 
or different kinds of growth models. ${ }^{61}$ During the Eurozone Crisis, however, the continued economic heterogeneity of the Eurozone was understood as a fundamental threat to the stability of the monetary union.

Measures and reforms to address the Eurozone Crisis have responded to the problem of heterogeneity in a number of distinct but interrelated ways. On the one hand, a number of general reforms have been implemented that seek to affect how Member States govern (e.g., European Semester, Fiscal Compact, Banking Union, Excessive Deficit Procedure, Macroeconomic Imbalance Procedure). On the other hand, the Union level has sought to overhaul individual Member State economies through conditionality attached to financial assistance. The solidarity that markets assumed, in other words, was borne out, but it was instrumentalised in in the quest to bring about economic and structural convergence in the Eurozone. It was used to introduce the possibility of employing public authority to reorganise the economic practices of non-conforming Member States The response to the Eurozone Crisis has thus sought to address the problem of economic heterogeneity through measures of an explicitly emergency political nature that suspended the ordinary political process in particular Member States, and through the construction governmental arrangements that reshape that process permanently.

EU actors have presented the reforms undertaken in emergency mode in the language of 'completing' (Juncker et al 2015), 'deepening' (Commission 2017) and making the EMU 'genuine' (Van Rompuy 2012). In effect, they do no such thing as they radically transform the EMU's embodied vision of economic government. It is nevertheless worth examining how European elites conceptualise both the problem and how the emergency political measures respond to it. From such reflections it is possible to outline the contours of an emerging constitutional imaginary that differs in important respects from the neoliberal theory of federalism that informed the public law form of the Maastricht EMU.

\footnotetext{
61 Engelbert Stockhammer, Cédric Durand, and Ludwig List, "European Growth Models and Working Class Restructuring: An International Post-Keynesian Political Economy Perspective," Environment and Planning A: Economy and Space 48, no. 9 (2016): 1804-28, https://doi.org/10.1177/0308518X16646373; Alison Johnston and Aidan Regan, "Introduction: Is the European Union Capable of Integrating Diverse Models of Capitalism?," New Political Economy 23, no. 2 (March 4, 2018): 145-59, https://doi.org/10.1080/13563467.2017.1370442; Chris J. Bickerton, European Integration: From Nation-States to Member States (Oxford: Oxford University Press, 2012), chapter 4, https://doi.org/10.1093/acprof:oso/9780199606252.001.0001.
} 


\section{Generating Federal Governmental Authority}

The 2015 'Five Presidents Report' explicitly addressed the nature of the relationship between the emergency politics of the crisis and its problematic relationship with the existing institutional structure of the EU. The crisis "forced national governments and EU institutions to take quick and extraordinary steps." Such steps were necessary to conserve the "house that was built over decades but only partially finished," but they "need to be turned into a lasting, fair and democratically legitimate basis for the future ... It is now high time to reinforce its foundations." In particular, "a lot more needs to be done to improve economic policies." 62 The question is what and how such changes affect the public law structure of the Eurozone?

The Report stresses that " $[\mathrm{t}]$ he euro is more than just a currency. It is a political and economic project" in which "monetary sovereignty" is shared. 63 In line with the Haykeian vision of federation, this entails the sacrifice of a number of political freedoms at the Member State level when it comes to economic policy as "national adjustment tools," among other things, have been given "up on entry." 64 The EMU's crisis, however, means that a number of additional constraints on the economic policies of Member States need to be established and those that already exist need to be better monitored and enforced; most importantly through the European Semester. In this regard, the Commission's “Country-Specific Recommendations need to be concrete and ambitious" but "[a]t the same time, they should remain 'political', i.e. Member States should have a degree of freedom concerning the exact measures to be implemented."65 The Report thereby refers back to the notion of Member State plurality that the Delors Report presented. This plurality, however, is mainly presented as a problem and the Member States' room of policymaking manoeuvre ought to be limited to having a certain influence on how exactly to "maintain sound policies and embark on reforms that make their economies more flexible and competitive."66 The question for Member States, in other words, is not whether to adopt certain reforms, but only how.

\footnotetext{
62 Jean-Claude Juncker et al., “Completing Europe’s Economic and Monetary Union” (Brussels: European Commission, 2015), 4.

63 Juncker et al., 4.

${ }^{64}$ Juncker et al., 4.

65 Juncker et al., 9 emphasis added.

${ }^{66}$ Juncker et al., 4 emphasis added.
} 
In the Report, the further strengthening of the European surveillance apparatus is to be accompanied by steps towards a political union that provides "the foundation for all of the above [the various reforms] through genuine democratic accountability, legitimacy and institutional strengthening." 67 As such, the Report acknowledges that the reforms entail a limitation on democracy in the Member States. While the Report is vague on the question of how this will be compensated for at the European level, ${ }^{68}$ the centrality of the notion of 'genuine' legitimacy and accountability reflects the notion that the strengthening of governmental capacity at the European level demands also a new form of political authorisation and even a new political form for the EMU:

In spite of the undeniable importance of economic and fiscal rules and respect for them, the world's second largest economy cannot be managed through rule-based cooperation alone. For the euro area to gradually evolve towards a genuine Economic and Monetary Union, it will need to shift from a system of rules and guidelines for national economic policy-making to a system of further sovereignty sharing within common institutions. ${ }^{69}$

The EMU must shift towards a system in which the Union level has "its own fiscal capacity and a means of imposing budgetary and economic decisions on its members." 70 The realisation of the ideology enshrined in the EMU, in other words, demands a comprehensive European governmental capacity to intervene in and direct Member State economic policies.

The argument that political freedom at the Member State level makes the EMU vulnerable to internal collapse or foreign domination is, in essence, an (Hobbesian-Schmittian) argument for the necessity of concentrating sovereign power. This was precisely the message conveyed by the title of Juncker's 2018 'State of the Union' address: “The Hour of European Sovereignty.” Here Juncker presents the relevance of the question of 'European sovereignty' in the context of Europe's place in the world at the present conjunction: " The geopolitical situation

\footnotetext{
${ }^{67}$ Juncker et al., 5 .

${ }^{68}$ Ben Crum, "Parliamentary Accountability in Multilevel Governance: What Role for Parliaments in Post-Crisis EU Economic Governance?," Journal of European Public Policy 25, no. 2 (2018): 268-86.

69 Juncker et al., “Completing Europe’s Economic and Monetary Union,” 5.

70 European Commission, "A Blueprint for a Deep and Genuine Economic and Monetary Union: Launching a European Debate," Communication from the Commission (Brussels: European Commission, November 30, 2012), 31 emphasis added.
} 
makes this Europe's hour: the time for European sovereignty has come." 71 The 'geopolitical situation' refers to a number of things (Russia, China, Trump, international terrorism, etc.) and is defined by instability and unpredictability. As such, Europe can no longer rely on the benevolence of other powers but must take "its destiny into its own hands" and develop what Juncker calls “'Weltpolitikfähigkeit' - the capacity to play a role, as a Union, in shaping global affairs." Europe, in other words, "has to become a more sovereign actor in international relations." 72 This capacity, however, requires 'unity' and places certain requirements on how the EU governs itself internally. That is, Europe's capacity to shape its own fate in the world must not be compromised by internal differences and disagreements.

European unity is equally important to French president Emmanuel Macron, who has invoked the necessity of European sovereignty on a number of occasions. In his speech on accepting the Charlemagne Prize for, indeed, European Unity, Macron outlines four "commandments" or "categorical imperatives for action." The first - "let's not be weak, let's not be passive - is that of European sovereignty." The problem of European sovereignty is thus, like in Juncker's State of the Union, that of self-determination; that is, the refusal "to allow others to decide for us." In order for Europe to become a powerful player in global politics, however, it must be united and as such the "second imperative is: let's not be divided." "Divisions," he claims, "push us into siege warfare, the very same that made Europe suffer one of its worst torments a century ago now." The external dimension of sovereignty is thus intricately linked to its internal dimension. In order to realise European sovereignty, then, Europe must move towards further "economic, fiscal and social convergence." In particular, Europe must work towards "a stronger, more integrated Euro Area with its own budget,"73 since "sustainable economic power can only be constructed around a single currency," as Macron put it in his Sorbonne speech. ${ }^{74}$ Or as Juncker (2018: 10) put it, "The euro must become the face and the

\footnotetext{
71 Jean-Claude Juncker, "State of the Union 2018: The Hour of European Sovereignty," 5, https://ec.europa.eu/commission/sites/beta-political/files/soteu2018-speech_en_0.pdf, emphasis in original.

72 Juncker, 5.

${ }^{73}$ Emmanuel Macron, "Speech by M. Emmanuel Macron, President of the Republic, on receiving the Charlemagne Prize" (Speech, Aix-la-Chapelle, May 10, 2018), https://www.elysee.fr/emmanuel-macron/2018/05/10/speechby-m-emmanuel-macron-president-of-the-republic-on-receiving-the-charlemagne-prize-1.en.

${ }^{74}$ Emmanuel Macron, "Initiative pour l'Europe - Discours d'Emmanuel Macron pour une Europe souveraine, unie, démocratique.” (Speech, Paris, September 26, 2017), https://www.elysee.fr/emmanuelmacron/2017/09/26/initiative-pour-l-europe-discours-d-emmanuel-macron-pour-une-europe-souveraine-
} 
instrument of a new, more sovereign Europe."75 In order to serve this role, however, "we must first put our own house in order by strengthening our Economic and Monetary Union ... Without this, we will lack the means to strengthen the international of role of the euro. We must complete our Economic and Monetary Union to make Europe and the euro stronger."76

\section{Governing the Eurozone}

While the Crisis revealed that the constraint on the governmental capacity of Member States had not worked as envisioned by the original framers of the EMU, it also revealed, as noted above, that the EMU had worked in terms preventing the emergence of an effective union-level governmental power. When it came to the federal level's governmental capacity, the neoliberal theory of federation was largely right: the Member State governments could not reach a true agreement on a general crisis response that would involve Eurozone-wide measures. Because the Crisis threatened both the stability of the EMU as well as the general belief in and support for a market based economic order, however, this absence of federal governmental capacity turned out to be a problem. In reflections on the future of the Eurozone and of Europe's ability to address its present and future challenges, this remains a key concern. As highlighted by Macron and Juncker, the EMU must develop its own fiscal capacity. ${ }^{77}$ Without this, the European level does not have access to the means necessary for developing an economic programme independently of the unanimous consent of the Member States. Governing the Member States from the centre is crucial, but without its own means, the governmental capacity of the European level will remain weak.

Within the monetary dimension of the EMU, however, the European level does have access to its own means of governmental intervention: the ECB's monetary policy. While the substantive content of the Maastricht Treaty envisioned this instrument to be strictly circumscribed by the price stability mandate, the ECB's actions in addressing the Eurozone Crisis have moved well beyond this limited remit. Through (in)formal threats to (or promises

\footnotetext{
unie-democratique, my translation. In the French original: "une puissance économique durable ne peut se construire qu'autour d'une même monnaie."

75 Juncker, “State of the Union 2018: The Hour of European Sovereignty,” 10.

76 Juncker, 10-11.

77 See also Federico Fabbrini, “A Fiscal Capacity for the Eurozone: Constitutional Perspectives” (European Parliament, February 2019),

https://www.europarl.europa.eu/RegData/etudes/IDAN/2019/608862/IPOL_IDA(2019)608862_EN.pdf.
} 
to protect) Member State governments; through its role in designing, supervising and executing reforms in 'programme' countries; through the 'whatever it takes' message of the Outright Monetary Transactions (OMT) and the Quantitative Easing (QE) programmes, the ECB's involvement in governing the Eurozone and its constituent economies is broad and deep. While the ECB was not originally 'meant' to take on such a role, there is certain logic to central place that the ECB assumed. If the Eurozone Crisis was a true existential crisis for the EMU, the ECB was the only institution with both a clear Union-wide mandate and the available means of acting directly and immediately on the crisis without first having to secure formal agreement, without having to "consult a senate or the people," 78 on the nature of any intervention. It could act unilaterally to fill the governmental or "political vacuum created at the centre of the EMU."79

The ECB's actions during the crisis emphasised that governmental capacity could be exercised effectively in the Eurozone. While not the kind of sweeping power exercised by, e.g., the US federal administration in the context of the New Deal and, to a lesser extent, in the Financial Crisis, this demonstrated the potential capacity of a European level government. This potential has informed the vision of the Eurozone's constitutional future presented by members of the ECB's Executive Board.

In his 'whatever it takes'-speech, Mario Draghi noted that the Eurozone would have to undergo reforms that meant that "much more of what is national sovereignty is going to be exercised at supranational level." Specifically, he noted "that common fiscal rules will bind government actions on the fiscal side." 80 This notion is to a large extent in line with the discussion above and he did not detail further what kind of European level governmental capacity this would entail. In public addresses after the OMT intervention, however, Draghi developed a specific conception of sovereignty that is, presumably, shaped by the experience of the OMT and QE programmes and which would have to inform Eurozone governance in the future.

\footnotetext{
${ }^{78}$ Carl Schmitt, Dictatorship (Cambridge: Polity Press, 2014), 9. Schmitt is referring to Bodin's account of the Roman institution of dictatorship.

79 Wolfgang Streeck, "Heller, Schmitt and the Euro," European Law Journal 21, no. 3 (2015): 370, https://doi.org/10.1111/eulj.12134.

${ }^{80}$ Mario Draghi, "Verbatim of the Remarks Made by Mario Draghi” (Speech, Global Investment Conference, London, July 26, 2012), https://www.ecb.europa.eu/press/key/date/2012/html/sp120726.en.html.
} 
According to Draghi, there are two ways "to look at sovereignty." The former, 'Bodinian' view, sees it as a "normative" concept, which "is defined in relation to rights: the right to declare war, and treat the conditions of the peace, to raise taxes, to mint money and to judge in last resort," 81 and, one might add, the right to make laws autonomously. To Draghi, however, "True sovereignty is reflected not in the power of making laws." 82 Sovereignty, rather, is "the ability to deliver in practice the essential services that people expect from government." 83 That is, sovereignty is "the ability to control outcomes and respond to the fundamental needs of the people: what John Locke defines as their 'peace, safety, and public good.'”84 Conversely, "A sovereign that is not capable of effectively discharging its mandate would be sovereign only in name." 85 This "positive" conception of sovereignty, derived from Draghi's reading of Locke and Madison's Federalist no. 45, offers "essentially the right way to think about sovereignty" and "it needs to be the guiding principle when deciding which powers should be at national or European levels." In the final instance, then, "the sovereign exists only as a fiduciary power to act for certain ends. It is the ability to achieve those ends that defines, and legitimises, sovereignty." 86

In Draghi's conception, sovereignty is defined through the question of governmental capacity, "the actual ability to control things." 87 Draghi dismisses the reverse definition, i.e., from perspective of the right to express political will freely, "rightful authority," 88 because "[t]he ability to make independent decisions does not guarantee countries such control. In other words, independence does not guarantee sovereignty." 89 The link between these two dimensions, however, does not disappear. In the original EMU structure, Member States

\footnotetext{
${ }^{81}$ Mario Draghi, “Europe's Pursuit of 'a More Perfect Union'” (Lecture, Harvard Kennedy School, Cambridge, MA, October 9, 2013), https://www.ecb.europa.eu/press/key/date/2013/html/sp131009_1.en.html.

82 Mario Draghi, "Sovereignty in a Globalised World" (Speech, Award of Laurea honoris causa in law from Università degli Studi di Bologna, Bologna, February 22, 2019), https://www.ecb.europa.eu/press/key/date/2019/html/ecb.sp190222 fc5501c1b1.en.html.

83 Draghi, "Europe's Pursuit of 'a More Perfect Union."”

${ }^{84}$ Draghi, "Sovereignty in a Globalised World."

85 Draghi, "Europe's Pursuit of 'a More Perfect Union.'”

86 Draghi, emphasis added.

${ }^{87}$ Loughlin, "The Erosion of Sovereignty," 63.

88 Loughlin, 63.

${ }^{89}$ Draghi, "Sovereignty in a Globalised World."
} 
retained the 'rightful authority' to define economic policy according to will. Their capacity to realise this will, however, was supposed to be constrained by the federal structure. In the 'new EMU', however, the relationship between rightful authority and capacity is reconstituted on the basis of the latter: rightful authority should follow from the capacity to exercise it effectively. The reference to Federalist no. 45 is notable in this respect. Devoted to the question of the "danger from the powers of the Union to the state governments," 90 Madison outlines a conception of the distribution of powers between the different levels as resting on the question of how best to ensure "the public good, the real welfare of the great body of the people." 91 The question of the sovereignty of the States vs the governmental powers of the Union is thus presented as one regarding which level is best capable of realising the will of the people. From this perspective, insisting on the rights of the States against the Union is potentially a betrayal of the promise of self-government because it makes the realisation of the political will or welfare of the people more difficult, if not impossible. The Union's powers, according to this perspective, are legitimate because they make self-government possible, and thus sovereignty meaningful, through superior governmental capacity.

Like Juncker and Macron, Draghi sees sovereignty ultimately as a question of being able to control one's fate. The question of control, however, is two-sided. On the one hand, one might want to 'take back control' over the laws of the community, as Brexit is a manifestation of. This understanding emphasises the right to make laws freely but does not necessarily address whether those laws will be effective in giving the community control over its fate in material terms. On the other hand, then, one may emphasise the capacity to control one's fate in a materially meaningful way. This latter approach informs the perspective of another former ECB official, Benoît Cœuré. According to Cœuré, the struggle against 'Brussels' or 'Frankfurt' is fundamentally misguided because the relevant contemporary problems concern developments at the global level. And in the global realm sovereignty is only possible "through European

\footnotetext{
${ }^{90}$ James Madison, "Federalist No. 45," in The Federalist Papers, by Alexander Hamilton, James Madison, and John Jay, ed. Michael A. Genovese (New York: Palgrave Macmillan, 2009), 97.

${ }^{91}$ Madison, 98.
} 
integration" because only this gives Europe and its states and citizens the capacity to determine their own fates. ${ }^{92}$

The notion of sovereignty that Cœuré presents is similar to Draghi's: sovereignty is something that expresses a political community's ability to effect change in the world: "This is what the EU gives to the people of Europe: a way of sustaining an open international order while also bending its outcomes to their will."93 This statement captures the notion of sovereignty as the people's capacity for self-determination succinctly. Only by acting through the European level can 'the people of Europe' be the master of its own fate. ${ }^{94}$ Because the individual state is unable on its own to affect the factual conditions of global trade and finance in a meaningful way, the EU offers a stronger avenue for the exercise of democratic sovereignty: "the EU gives its citizens more democratic control over globalisation than is afforded to people in other countries." In effect, assertions of national sovereignty against this project, in line with Madison, diminish democratic sovereignty and constitute a betrayal of the people. To extrapolate this view somewhat: because the federal level is the only level of government that can meaningfully control the fate of Europe in the face of threats arising from the market, pandemics, the environment or from foreign powers, Europe, not the Member States, must channel sovereignty. It must therefore be in a position to govern effectively on behalf of the Eurozone as a whole and, as highlighted by the Five Presidents' Report, be able to intervene in and control the internal affairs of the Member States.

\section{Conclusion: Ideology and Governmental Capacity in the Time of Covid-19}

Despite the many reforms of the EMU in emergency mode and its influential proponents, 'European sovereignty' as an expression of a comprehensive European governmental capacity with respect to economic affairs remains an unrealised constitutional imaginary. Important political currents at the Member State level continue to resist the idea and there are considerable practical obstacles to its full realisation. The response to the Covid-19 Crisis that struck in the spring of 2020 also highlights the incomplete nature of European level

\footnotetext{
92 Benoît Cœuré, "Taking Back Control of Globalisation: Sovereignty through European Integration” (Contribution to 2018 Schuman Report on Europe, Frankfurt am Main, 2018), https://www.ecb.europa.eu/press/inter/date/2018/html/ecb.in180328.en.html.

93 Cœuré.

${ }^{94}$ On the notion of 'the people of Europe' in ECB discourses, see Lokdam, “'We Serve the People of Europe."”
} 
governmental capacity and the ECB remained Europe's first line of defence in responding to the Crisis.

The Covid-19 Crisis reiterated that ECB interventions are inadequate. Such interventions highlight that the European level can act effectively, but also that its governmental capacity is incomplete and asymmetric (and largely un-democratic). The creation of a European recovery fund seeks to some extent to rectify this. Regardless of its merits or shortcomings, this initiative expresses the view that "the crisis has underlined how important it is that the Union is able to react fast and flexibly to put in place a coordinated European response."95 It may not offer the kind of governmental apparatus associated with the US federal government, but it includes an important innovation in European economic government: the possibility of raising funds for public spending and investments through the issue of common debt. Such funds, furthermore, are to be channelled through the framework of the European Semester, thus allowing the Commission, in its own words, to control that the funds are used "to ensure convergence and a sustainable economic recovery. [Since c]arrying out reforms and investing in the EU's common priorities, notably green, digital and social resilience will help create jobs and sustainable growth, while modernising our economies, and allow the Union to recover in a balanced, forward-looking and sustained manner."96 The recovery fund, in other words, builds on Eurozone Crisis measures and reforms to shape and reshape Member State economic policies and structures in response to the Crisis. As such, while it does not go all the way, it is a further step down the road to European sovereignty as envisioned by Juncker and Macron.

More than anything else, however, the response to the Covid-19 Crisis highlights the increasing irrelevance of the neoliberal theory of federalism in prevalent understandings of the main problems facing the EU and the Eurozone. The problems are not understood as resulting from a crisis of governmental overload, governments are not doing too much. The concern is, rather, to develop the governmental capacity necessary to address large-scale issues such as pandemics and climate change. Thus, while the response to the Eurozone Crisis in many ways pursued neoliberal policies using authoritarian means, the Covid-19 crisis response suggests

\footnotetext{
95 https://ec.europa.eu/info/live-work-travel-eu/health/coronavirus-response/recovery-plan-europe en [accessed 28 July 2020].

${ }^{96}$ https://ec.europa.eu/info/sites/info/files/2020mff covid recovery factsheet.pdf, emphasis added [accessed 28 July 2020]
} 
that the governmental mechanisms introduced can be put to other uses. The transformation of the European governmental framework and its associated vision of European sovereignty, in other words, are ideologically open-ended in terms of policy outcomes. This in itself, however, means that in terms of its theory and ideology of public authority and public law it is not: it is an ideology that emphasises the need for activist public authority in bringing about politically decided outcomes. Thus, while the strengthening of the European centre may have targeted a streamlining of Member State economic structures and practices along neoliberal lines, it represents a transformation of the EMU's constitutional form that departs from the neoliberal theory of federal government. It opens for the possibility of employing public powers at the European level for purposes other than those presently pursued (say, distributional equalisation, corporate taxation, 'green new deal').

In its quest for economic convergence, furthermore, the European governmental apparatus 'threatens' to undermine one of the key structural elements that made comprehensive action at the European level so difficult in both practice and according to the neoliberal theory: the economic heterogeneity and diversity of the Member States' material constitutions. If successful in bringing about 'true convergence,' in other words, the new EMU would, following Hayek's logic, pave the way for the Eurozone to emergence as an integrated and much more homogenous economy. This would, in turn, allow for the kind of 'true agreement' that makes the interventionist exercise of federal governmental powers possible; without reforming the decision-making procedures at the European level, that is. Whether the Eurozone would in that case still be a federation is an open question. As Larsen notes, the basis of the federation is that the constituent parts are too alike to remain fully separate, but too different to subject themselves to a unitary constitution. ${ }^{97}$ One can, of course, only speculate on this, but 'true convergence' may provide the material constitutional basis for a more unitary (federal) state constitution, invested with the governmental capacity to radically transform the outlook of economic government in Europe and the possibility of reaching agreements on how to use it. Whether the same is true for the EU beyond the Eurozone is another matter.

"The future course of European integration depends on the answer" to the question of sovereignty. ${ }^{98}$ Given the coexistence of centripetal and centrifugal forces in contemporary

97 Larsen, The Theory of the Federation and the European Union, chapter 4.

98 Dieter Grimm, The Constitution of European Democracy (Oxford: Oxford University Press, 2017), 41. 
Europe, this is undoubtedly true. However, the question of sovereignty is not merely a question of legal and political form or kompetenz-kompetenz. It is as much a question of the ideology of governmental authority. The way that the constitutional structure organises the exercise of governmental power with regard to economic matters is unavoidably a question with distinct ideological overtones. What it is possible to do through the use of public power is just as important, if not more, than what is actually done for understanding the ideological shade of any constitutional regime. Public law can never be ideologically neutral.

In the Eurozone context, this represents a peculiar conundrum for progressive political imaginaries. Eurozone Crisis reforms at both the Member State and European levels have been largely neoliberal and have taken place in emergency mode with little or no democratic input. The resulting centralisation of governmental capacity, however, has created the possibility for Eurozone-wide economic programmes that go in a very different direction. This is not to say that the reformed EMU necessarily produces progressive outcomes. It does not. What it does do is to shift the structural framework of economic policymaking from a modality of governing that relies on depoliticisation and the 'primacy of the market' to one that is based on the 'primacy of politics.' It allows for the political control of economic affairs. While this is not enough for a progressive politics to emerge, it has historically been a necessary condition for it. ${ }^{99}$ It is, after all, only through the exercise of coercive public power that any political control over society's productive resources can be obtained. In other words, if a European progressive and green politics is to possible, one may have to embrace European sovereignty. The challenge is to make that sovereignty democratic.

\footnotetext{
${ }^{99}$ See Berman, The Primacy of Politics: Social Democracy and the Making of Europe's Twentieth Century.
} 
Author(s): Hjalte Lokdam

Title: The Ideological Shade of the Constitutional Order: Public Law and Political Economy in the Eurozone

iCourts Working Paper Series, No. 231, 2021

Publication date: 7/January/2021

URL: http://jura.ku.dk/icourts/working-papers/

(C) Author

iCourts Working Paper Series

ISSN: 2246-4891

Hjalte Lokdam, ESRC Postdoctoral Fellow in the European Institute, LSE E-mail: h.c.lokdam@lse.ac.uk

The iCourts Online Working Paper Series publishes pre-print manuscripts on international courts, their role in a globalising legal order, and their impact on politics and society and takes an explicit interdisciplinary perspective.

Papers are available at http://jura.ku.dk/icourts/

iCourts

- The Danish National Research Foundation's Centre of Excellence for International Courts The Faculty of Law

University of Copenhagen

Karen Blixens Plads 16

2300 Copenhagen $S$

E-mail: icourts@jur.ku.dk

Tel. +4535322626 